Jurnal Terapung : Ilmu - Ilmu Sosial , Vol. 3, No. 1, Maret 2021 ISSN: 2656-2928

\title{
PENGEMBANGAN PENDIDIKAN NASIONAL BERBASIS BUDAYA LOKAL
}

\author{
Richa Dewi Rahayu \\ Universitas Tanjung Pura Pontianak \\ Email: richa.dewirh@gmail.com
}

\begin{abstract}
ABSTRAK
Dalam dunia ini terdapat ratusan bahkan ribuan budaya, ras, suku, bahasa dan negara. Melalui pendidikan kita tidak hanya diberi pelajaran serta pengetahuan tentang bahasa, suku, ras, agama, budaya dan neraga kita sendiri melainkan juga ras, suku, bahasa, negara lain tujuannya adalah agar kita dapat mengetahui suku, bahasa, budaya, negara lain sehinngga kita dapat berinteraksi tidak hanya dengan orang-orang dinegara kita sendiri melainkan dengan orang-orang yang ada di negara lain dengan menjalin hubungan yang baik dengan negara lain baik dalam bentuk kerja sama dalam bidang ekonomi, pendidikan dan sebagainya.
\end{abstract}

Kata kunci: Pengembangan pendidikan, berbasis budaya

\begin{abstract}
In this world there are hundreds or even thousands of cultures, races, tribes, languages and countries. Through education we are not only given lessons and knowledge about our own language, ethnicity, race, religion, culture and spirit but also race, ethnicity, language, other countries, the goal is that we can know other ethnicities, languages, cultures, countries so that we can interact not only with people in our own country but with people in other countries by establishing good relationships with other countries in the form of cooperation in the fields of economy, education and so on.
\end{abstract}

Key words: Educational development, based on culture

\section{PENDAHULUAN}

Kehidupan manusia senantiasa berkembang. Manusia mengembangkan dirinya dengan belajar, pembelajaran yang diperoleh dapat melalui jalur formal maupun nonformal. Manusia yang senantiasa belajar akan membawa perubahan dalam bidang pendidikan. Pada abad saat ini, pendidikan merupakan hal yang memiliki kedudukan yang penting dalam hidup manusia. Pada zaman moderen saat ini, pendidikan makin berkembang kearah yang lebih baik dan maju. Banyaknya perkembangan pada dunia pendidikan dapat dilihat dari semakin banyaknya di dirikan sekolah-sekolah baik yang bertaraf nasional maupun internasional, baik sekolah negeri maupun sekolah swasta. Perkembangan ini tentunya tidak terlepas dari pemikiran manusia yang telah maju. Manusia menganggap pendidikan sebagai bagian dari kebutuhan hidup yang harus dipenuhi. Pendidikan menuntut serta menjadikan manusia yang memiliki ahlak yang baik serta berbudaya. Tidak dapat dipingkiri bahwa pendidikan tidak terlepas dari budaya Richa Dewi Rahayu | 17 
manusia. Keberadaan budaya suatu bangsa akan mempengaruhi sistem pendidikan bangsa itu sendiri. Pendidikan tidak akan berjalan serta berkembang dengan baik jika tidak sesuai dengan budaya yang dianut. Pendidikan harus sejalan dan selaras dengan budaya yang dianut oleh masyarakatnya. Budaya suatu bangsa memiliki peranan penting dalam upaya peningkatan mutu pendidikan, serta memberikan dampak yang baik dalam perkembangan pendidikan maupun kemajuan belajar siswa. Banyak upaya yang dapat dilakukan dalam peningkatan mutu,proses, serta prestasi belajar siswa disekolah melalui pendidikan yang melibatkan serta memperhatikan nilai penting kebudyaan. Pentingnya budaya ini telah banyak memberikan dampak positif pada perkembangan pendidikan serta kerberhasilan belajar siswa, sehingga budaya telah menjadi bagian dari kurikulum pendidikan.

Kebudayaan bukan hanya menjadi ciri khas suatu bangsa yang dapat membedakan budayanya dengan bangsa lain, melainkan memiliki maanfaat bagi hidup manusia. Adapun manfaat budaya bagi manusia adalah:

1. Menumbuhkan silap nasionalisme

Perbedaan budaya yang ada akan menimbulkan rasa cinta tanah air, kerena keanekaragaman budaya adalah suatu kekayaan yang dimiliki suatu bangsa. Kebudayaan juga dapat menjadi daya tarik dan kekayaan yang dimiliki suatu bangsa. Kebudayaan menyimpan nilai-nilai luhur yang memiliki keunikan dan kegunaannya masing-masing.

2. Identitas bangsa di mata Internasional

Dengan kemajemukan budaya yang ada bisa menjadi identitas diri suatu bangsa. Kita tahu bahwa pakaian batik merupakan bagian asli dari budaya indonesia yang telah mendunia. Orang-orang yang berasa di luar pulau Indonesia menhetahui bahwa batik merupakan hasil karya budaya asli indonesia. Hal itu merupakan salah satu identitas negara Indonesia, begitu juga dengan bangsa aborogin yang merupakan bangsa asli australia yang menjadi identitas negara australia. Oleh sebab itu fungsi dari kebudayaan ini adalah dapat mengenalkan negara kita kepada dunia Internasional begitu juga sebaliknay neraga laindapat mengenalkan budayanya kepada negara Indonesia.

3. Alat pemersatu bangsa

Keanekaragaman budaya kita tidak lantas membuat kita terpecah belah, dan hidup secara individu melainkan menjadi simbol kerukunan hidup masyarakat dan menjadi kekayaan budaya kita. Keunikan budaya yang di miliki bangsa akan berbeda dengan bangsa lainnya. Bhineka Tunggal Ika menjadi simbol persetuan bangsa indonesia di tengah beribu perbedaan budaya masyarakatnya.

4. Sebagai ikon pariwisata

Keanekaragaman budaya serta peninggalan masa lalu seperti tarian, bangunan, bahasa, dan artefak budaya lainnya, dapat menjadi magnet dalam bidang pariwisata,sehingga dapat menarik meinat para orang-orang asing untuk datang dan melihat keanekaragaman budaya yang ada, sehingga mereka dapat mengetahui apa saja kebudayaan yang ada.

5. Menambah pendapatan Nasional 
Adanay keanekaragaman budaya yang ada pada suatu negara akan berdampak pada bidang periwisata sehingga dapat mendatangkan para wisatawan untuk datang. Jika dikelola oleh negara, maka objek wisata tersebut akan menambah keuntungan yang masuk pada kas negara.

6. Memupuk rasa toleransi

Dengan adanya keberagaman budaya pada suatu negara dapat menumbuhkan rasa toleransi antar masyarakatnya.

7. Budaya adalah nilai-nilai yang memiliki suatu masyarakat dan di lembagakan dalam bentuk artefak budaya dapat dijadikan sumber pengetahuan, karena artefak budaya dari masa lalu bisa menjadi sumber informasi yang berharga.

\section{METODE PENELITIAN}

Pendekatan pada penelitian ini berfokus pada kesiapan guru dalam mengimplementasikan pendidikan nasional berbasis budaya lokal dilihat dari kesiapan sarana dan prasarana yang mendukung. Peneliti mencari informasi secara mendalam mengenai kesiapan, kendala, dan solusi yang dilakukan oleh guru dalam mengimplementasikan pendidikan berbasis budaya lokal. Fungsi lain dari penelitian ini adalah untuk mengetahui tingkat keberhasilan implementasi pendidikan berbasis budaya lokal di beberapa sekolahan yang terdapat di Kota Pontianak tahun Pelajaran 2019/2020. Dalam mengumpulkan data, peneliti menggunakan metode pengamatan secara langsung di lapangan dan melakukan wawancara dengan kepala sekolah, guru, serta peserta didik di Sekolah Dasar Negeri Kota Pontianak. Hakikat penelitian kualitatif adalah satu kegiatan sistematis untuk menemukan teori bukan untuk menguji teori atau hipotesis. Arti secara epistemologi paradigma kualitatif tetap mengakui fakta empris sebagai sumber pengetahuan tetapi tidak menggunakan teori yang ada sebagai bahan dasar untuk melakukan verifikasi. Dalam penelitian kualitatif, proses penelitian merupakan sesuatu yang lebih penting dibanding dengan hasil yang diperoleh. Peneliti sebagai instrumen pengumpul data dan merupakan suatu prinsip yang paling utama dengan keterlibatan penelitian alami. Proses pengumpulan data merupakan hasil penelitian yang dapat dipertanggungjawabkan.

\section{HASIL DAN PEMBAHASAN}

1. Hubungan Kebudayaan Dengan Pendidikan

Perkembangan ilmu pengetahuan dan teknologi yang pesat telah mengakibatkan adanya perubahan pada budaya masyarakat yang berlangsung cepat, perubahan budaya tersebut juga berakibat pada perubahan pendidikan. Baik budaya maupun pendidikan akan selalu berubah mengikuti perkembangan zaman. Perkembangan pendidikan yang cepat juga membawa perubahan pada keghidupan masyarakat. Perkembangan yang begitu cepat membuat masyarakat tidak menyadari bahwa mereka juga mengalami perubahan.

Baik budaya maupun pendidikan tidak dapat dipisahkan, karena pada hakekatnya pendidikan adalah proses pembudayaan. Hubungan antara pendidikan 
dan kebudayaan sangat erat, keduanya saling mempengaruhi satu sama lain. Kaitanya dengan hal ini, Prof. Zamroni menenkankan bahwa "Pendidikan yang tidak didasari oleh kebudayaan akan menghasilkan generasi yang tercabut dari kehidupan masyarakatnya sendiri. Menjadikan pendidikan steril dari kekayaan budayanya sendiri, dan berpotensi untuk menghasilkan enclave dalam masyarakat." Kehidupan masyarakat tentu tidak dapat terlepas dari budaya yang telah sejak dahulu dijaga, dilestarikan, serta di pertahankan. Kebudayaan seuatu bangsa menjadi tolak ukur pada tata kehidupan masyarakatnya. Tampa kebudayaan yang kokoh suatu bangsa tidak akan dapat menjadi manusia yang berbudaya, manusia yang beraklah mulia, manusia yang dapat menjunjung tinggi nilai-nilai luhur bangsanya.

Untuk mempertahankan nilai budaya suatu masyarakat, di perlukan suatu sarana untuk menyalurkan serta menyampaikan budaya beserta nilai-nilai yang terkandung di dalamnya, sarana tersebut adalah pendidikan. Melalui pendidikan, penyampaian dan penyaluran budaya dan nilai-nilai budaya akan mudah dilaksanakan. Dalam pendidikan disekolah, dirumah maupun dimasyarakat harus dapat memberikan pemahaman pada peserta bahwa pentingnya menjaga nilai-nilai luhur budaya.

Dalam kurikulum sekolah juga telah memasukan unsur budaya pada mata pelajaran. Adanya gambar maupun materi yang berisi tentang pakaian adat masyarakat maupun kehidupan masyarakat yang bekerjasama yang sering disebut Gotong Royong, telah membuktikan bahwa dalam proses pembelajaran anak tidak hanya di ajarkan membaca, menulis, dan menghitung tetapi juga mengajarkan siswa bagian dari kebudayaan bangsa.

Masyarakat tampa budaya tidak akan dapat memiliki tataan hidup yang teratur karna salah satu fungsi budaya adalah mengatur tata hidup masyarakat, tetapi budaya tidak akan berkembang dan tidak dapat terlestarikan jika tidak ada sarana untuk menyalurkannya, oleh sebab itu di perlukan pendidikan karena memalui pendidikanlah para generasi muda dapat mengetahui budaya serta dapat melestarikan budayanya.

2. Peran Budaya Dalam Dunia Pendidikan

Budaya merupakan salah satu alat ukur tata kelakuan dan hidup suatu bangsa. Setiap budaya di suatu negara tentu berbeda dengan negara lain. Budaya memiliki keunikan yang dapat membedakan masyarakat di suatu negara dengan bangsa lain. Budaya memiliki nilai-nilai yang penting bagi kehidupan manusia. Seperti halnya negara Indonesia yang kaya akan budaya, yang mana budaya merupakan hal yang penting untuk dilestarikan. Masyarakat Indonesia sangat menjunjung nilai-nilai masyarakatnya. Pancasila adalah ideologi negara Indonesia yang mana sila-sila tersebut bersumber dari nilai-nilai budaya Indonesia itu sendiri. Suatu nilai akan mudah diterima masyarakat jika nilai tersebut berasal dari nilai-nilai yang ada pada mesyarakat itu sendiri. Maka tidak dapat di pungkiri bahwa masyarakat berperilaku dan hidup bermasyarakat sesuai nilai-nilai budayanya. 
Nilai-nilai budaya ini tentunya harus dikembangkan serta dilestarikan. Pentingnya nilai-nilai budaya seperti nilai kesopanan,nilai kesatuan, nilai kerukunan,serta nilai-nilai yang lainnya, tentunya dapat menjadi pedoman dalam berperilaku. Jika generasi muda yang dalam kehidupannya menjunjung tinggi nilai-nilai budaya maka akan tercetak generasi muda yang berkualitas serta berkarakter mulia. Dalam dunia pendidikan pasti memiliki tujuan menjadikan peserta didik sebagai orang-orang yang berkualitas serta berkarakter mulia. Pendidikan yang memasukan nilai-nilai budaya dalam setiap mata pelajarannya akan memudahkan para peserta didik memahami bagai mana menjadi generasi penerus bangsa yang baik serta berkualitas. Nilai-nilai yang terkandung dalam budaya akan memberikan jalan terbukanya pemikiran peserta didik pada pentingnya menjaga nilai-nilai yang berasal dari bangsanya sendiri.

Budaya dapat menunjang pembelajaran yang baik bagi generasi muda, melalui budaya yang di salurkan dalam proses pembelajaran akan memberikan pemahaman pada siswa tentang budaya bangsa serta menjadikan peserta didik yang menanamkan nilai-nilai budaya pada dirinya sehingga dapat memilah nilainilai yang masuk dari luar yang dapat mengancam lunturnya budaya bangsa kita. Peran keluarga serta masyarakat tentunya sangat diperlukan guna melancarkan proses penyaluran nilai-nilai budaya melalui pendidikan

\section{Upaya Pengembangan Pendidikan Berbasis Budaya}

Ada banyak cara yang dapat ditempuh dalam memajukan pendidikan, salah satunya adalah budaya. Nilai-nilai yang terkandung dalan budaya dapat dijadikan pedoman dalam dunia pendidikan. Pendidikan yang berpedoman pada budaya bangsanya akan memudahkan dalam menciptakan generasi penerus bangsa yang berkualitas.

Konsep pendidikan berbasis budaya adalah pendidikan yang diselenggarakan untuk memenuhi standar nasional pendidikan yang diperkaya dengan keunggulan komparatif dan kompetitif berdasar nilai-nilai luhur budaya agar peserta didik secara aktif dapat mengembangkan potensi diri sehingga menjadi manusia yang unggul, cerdas, peka terhadap lingkungan dan keberagaman budaya, serta tanggap terhadap perkembangan dunia.

Pendidikan yang bertujuan menjadikan peserta didik sebagai manusia yang berkualitas,berkarakter serta berahlak mulia tidak akan dapat terwujud jika dalam penyelenggaraan pendidikan mengabaikan nilai budaya. Pada saat ini telah dikembangkan suatu strategi dalam dunia pendidikan yang mana bertujuan menciptakan manusia yang berbudaya sesuai dengan nilai-nilai budaya yang dianutnya yaitu pendidikan berbasis budaya. Budaya yang digunakan dalam pendidikan ini tentunya berasal dari budaya masyarakat itu sendiri. Pendidikan berbasis budaya ini menjadi model baru dalam pembelajaran. Untuk mencapai suatu sistem pendidikan yang maju dan berkembang sehingga dapat sesuai dengan standar mutu pendidikan maka haruslah dilandasi dengan nilai-nilai luhur 
budaya. Nilai luhur budaya yang dimaksud identik dengan pendidikan karakter yang harus ditanamkan pada peserta didik melalui berbagai strategi.

Menanamkan nilai-nilai luhur budaya pada diri peserta didik bukan merupakan hal yang mudah, namun bisa diupayakan dengan strategi keteladanan, program dan tindakan nyata, serta pembiasaan. Pembelajaran berbasis budaya merupakan penciptaan lingkungan belajar dan perancangan pengalaman belajar yang mengintegrasikan budaya sebagai bagian dari proses pembelajaran. Pendekatan ini didasarkan pada pengakuan terhadap budaya sebagai bagian yang fundamental dalam pendidikan, ekspresi, dan komunikasi gagasan, serta perkembangan pengetahuan.

Sebagai suatu strategi belajar, pembelajaran berbasis budaya mendorong terjadinya proses berpikir kreatif, dan juga sadar budaya. Pembelajaran berbasis budaya juga menjadikan budaya sebagai arena bagi peserta didik untuk mentransformasikan hasil observasi mereka ke dalam bentuk-bentuk dan prinsipprinsip yang kreatif tentang alam dan kehidupan. pembelajaran berbasis budaya berfokus pada penciptaan suasana belajar yang dinamis, yang mengakui keberadaan siswa dengan segala latar belakang, pengalaman, dan pengetahuan awalnya, dan memberikan kesempatan kepada siswa untuk bebas bertanya, berekspresi, dan membuat kesimpulan tentang beragam hal dalam kehidupan.

Pembelajaran berbasis budaya sebagai salah satu pendekatan pembelajaran alternatif, yaitu mengaitkan materi pembelajaran dengan konsep yang berasal dari budaya lokal di mana siswa itu berada. Melalui pengembangan konsep budaya lokal dalam proses pembelajaran, maka perkuliahan akan lebih mudah dipahami dan diterima oleh siswa.

Oleh sebab itu strategi untuk mengembangkan pendidikan berbasis budaya dapat dilakukan dengan berbagai cara diantaranya:

1. Memasukan unsur budaya dalam materi pembelajaran

Dalam proses pembelajaran hendaknaya dapat menanamkan nilai-nilai yang baik pada peserta didik, agar peserta didik tidak hanya dapat belajar tetapi menerapkan hal-hal yang baik yang telah ia pelajari dalam kehidupan seharihari. Materi ajar yang di ajarkan hendaknya mengandung nilai-nilai budaya bangsa agar anak dapat menanamkan nilai-nilai budaya itu dalam dirinya. Materi yang diajarkan sebaiknya tidak hanya berfokus pada materi menghitung, membaca maupun pemahaman perkembangan IPTEK melainkan juga pada tentang budaya bangsa yang ada. Oleh sebab itu materi yang diajarkan hendaknya memiliki nilai-nilai budaya serta memasukan unsur budaya di dalamnya.

2. Memberikan Materi Tentang Budaya

Dalam pembelajaran sebaiknya para peserta didik tidak hanya diajarkan tentang mata pelajaran matematika, IPA, pendidikan olahraga melainkan juga memberikan materi yang mengandung unsur budaya yang ada didalamnya, dengan pemberian mata pelajaran yang terfokis pada budaya akan memudahkan dalam menyalurkan budaya pada diri peserta didik.

Richa Dewi Rahayu | 22 
3. Menciptakan Suasana Kelas yang Menyenangkan Melalui permainan Berunsur budaya.

Pada zaman saat ini sering kita jumpai bahwa para anak lebih sering bermain dengan kecanggihan teknologi yang ada seperti game online. Padahan banyak sekali permainan yang menjadi ciri khas budaya kiat yang menarik. Pada saat proses pembelajaran guru tidak hanya berperan sebagai pemberi materi pembelajaran tetapi juga harus dapat menciptakan suasana kelas yang menyenangkan. Salah satu hal yang dapat gutu lakukan adalah dengan memberikan permainan dalam konteks pembelajaran yang yang memiliki unsur budaya. Dalam permainan yang telah dirancang oleh guru harus memperhatikan sikap dan tingkat kesopanan dan keteraturan siswa saat bermain.

4. Mengenalkan Bentuk Budaya dalam Pembelajaran

Saat proses pembelajaran berlangsung para guru harus dapat memberi pengetahuan kepada siswa dengan mengenalkan bentuk budaya pada siswa, seperti peninggalan sejarah berupa candi-candi yang menjadi ciri khas bangsa, mengenalkan pakaian adat bangsa, mengenalkan suku-suku yang ada dalam negera serta bentuk-bentuk budaya yang ada.

5. Menanamkan Nilai-Nilai Luhur pada Anak

Baik guru maupun orang tua harus mengenalkan serta menanamkan nilai-nilai luhur pada anak, agar anak dapat memahami nilai-nilai luhur yang berasal dari budaya bangsa kita sendiri. Penanaman nilai budaya harus dilakukan sejak dini, kerenanya para orang tua dan guru harus dapat bekarja sama dalam menanamkan nilai-nilai budaya pada anak.

6. Memberikan Contoh Perilaku yang Berbudaya

Baik guru maupun orang tua dalam mengajar dan mendidik haru memberikan contoh tauladan perilaku yang baik pada anak, hal ini agar anak dapat mencontoh perilaku berbudaya serta dapat menerapkannya dalam kehidupan sehari-hari.

Ada pun upaya-upaya diatas tentunya masih terdapat barbagai cara lain yang dapat kita lakukan dalam mengembangkan pendidikan yang berbasis budaya. Pendidikan yang berbasis budaya akan memudahkan dalam mendidik peserta didik dan sekaligus mencetak generasi muda yang berbudaya yang dapat menjunjung tinggi nilai-nilai luhur bangsa. Namun dalam pengembangan pendidikan budaya ini baik guru, orang tua, masyarakat serta pemerintah harus dapat bekerja sama dalam membangun pendidikan yang berlandaskan budaya bangsa.

\section{KESIMPULAN}

Kehidupan manusia akan selalu berkembang. Manusia senantiasa untuk selalu belajar, karena dengan belajar manusia dapat mendapat pebgetahuan yang luas yang berguna bagi dirinya. Disamping belajar manusia juga memiliki nilai-nilai luhur yang menjadi pedoman hidu dan bertingkah laku sekaligus menjadi ciri khas dirinya. Manusia selalu menjaga budaya yang telah turun temurun diberikan untuk di lestarikan. Dalam hal ini bahwa disamping manusia belajar manusia juga berupaya menjaga budayanya dan berpedoman pada budaya dalam hidup serta bertingkah laku. 
Adanya terobosan baru dalam dunia pendidikan melalui strategi pendidikan berbasis budaya dapat membuat manusia sebagai manusia yang tidak hanya belajar tetapi juga mengamalkan nilai-nilai budayanya sehingga dapat mencetak generasi muda yang tidak hanya cerdas dalam akademik melainkan menjadi manusia yang berbudaya. Oleh sebab itu pendidikan berbasis budaya ini harus di kembangkan melalui berbagai upaya yang dapat dilakukan oleh guru, otang tua serta masyarakat.

\section{DAFTAR PUSTAKA}

Adnyana, M. (2018). Integrasi kearifan lokal (lokal genius) dalam pembelajaran sains. Artikel Konseptual: Sains dan Kearifan Lokal.

Alfian, M. (2013). Potensi Kearifan Lokal dalam Pembentukan Jatidiri Dan Karakter Bangsa. Yogyakarta.

Anderson, L. W., \& Krathwohl, D. V. (2001). Kerangka pembelajaran untuk pembelajaran, pengajaran, dan assesmen. Yogjakarta: Pustaka Pelajar.

Arikunto, S. (2006). Dasar-dasar evaluasi pendidikan. Jakarta: PT Bumi Aksara.

Astute, E. P., \& Budiyono, S. (2017). Desain model pembelajaran matematika berbasis budaya di sekolah dasar. Jurnal Pendidikan Surya Edukasi (JPSE), 3 (1), 75-80.

Azizahwati,. Armadi, A. (2015). Pengembangan modul pembelajaran fisika SMA berbasis kearifan lokal untuk meningkatkan hasil belajar siswa. Riau: Universitas Riau.

Bakhtiar, A. M., \& Nugroho, A. S. (2016). Curriculum development of environmental education based on local wisdom at elementary school. International Journal of Learning, Teaching, and Educational Research, 20-28.

Dariyo, A. (2012). Dasar-dasar pedagogi modern. Jakarta: PT Indeks.

Depdiknas. (2008). Panduan Pengembangan Bahan Ajar. Jakarta: Direktorat Jendral Manajemen Pendidikan Dasar dan Menengah.

Fajarini, U. (2014). Peran kearifan lokal dalam pendidikan karakter. Jurnal Sosio Didaktika. 1(2), 118-127.

Hamalik, O. (2001). Proses belajar mengajar. Jakarta: Bumi Aksara.

Haryanto, J. T. (2014). Kearifan lokal pendukung kerukunan beragama pada komunitas tengger malang jatim. Jurnal Analisa, 21(02), 201-213.

Latifah, Ngalimun, Andi Setiawan, M, \& Haji Harun, M. (2020). Kecakapan Behavioral Dalam Proses Pembelajaran PAI Melalui Komunikasi

Richa Dewi Rahayu | 24 
Jurnal Terapung : Ilmu - Ilmu Sosial , Vol. 3, No. 1, Maret 2021 ISSN: 2656-2928

Interpersonal. Bitnet: Jurnal Pendidikan Teknologi Informasi, 5 (2), 36-42. https://doi.org/10.33084/bitnet.v5i2.1747

Nurkancana, W. \& Sunartana, P. P. N. (1990). Evaluasi hasil belajar. Surabaya: Usaha Nasional.

Suryabrata, S. (2008). Psikologi pendidikan. Jakarta: PT Raja Grafindo Persada.

Sutarno. (2007). Pendidikan multikultural. Jakarta: Direktorat Jendral Pendidikan Tinggi, Depdiknas.

Wibowo, A., \& Gunawan. (2015). Pendidikan karakter berbasis kearifan lokal di sekolah (konsep, strategi, dan implementasi). Yogyakarta: Pustaka Pelajar.

Wijaya, A. (2012). Pendidikan matematika realistik: suatu alternative pendekatan pembelajaran matematika. Yogyakarta: Graha Ilmu. 